Jurnal Psikologi Teori dan Terapan

2015, Vol.6, No. 1, 50-53, ISSN: 2087-1708

\title{
Psychological Well Being dan Motivasi Kerja Pada Pegawai Dinas Pendidikan
}

\author{
Kinanthi Kawuryaning Laksmi ${ }^{1}$, dan Meita Santi Budiani \\ Program Studi Psikologi Universitas Negteri Surabaya
}

\begin{abstract}
The purpose of this research was to examine the relationship between psychological well being and working motivation of employees. The method used in this study was a quantitative correlational design. The subjects of this study were 64 employees of bureau of education level III at "X" city, which were selected by using population sampling technique. Data of psychological well-being and working motivation were obtained by using Likert scales. The technique of data analysis in this study was Pearson's product moment. The result of this study shows that the coefficient correlation is 0.788 in the Significant level of 0.000. The result means that the hypothesis is accepted, that there is positive correlation between psychological well-being and working motivation. The result also indicates that $78.8 \%$ of working motivation influenced by psychological well-being and the rest of it $21.2 \%$ influenced by other variables that were not measured in this study.
\end{abstract}

Keywords: Psychological well being, work motivation

\begin{abstract}
Abstrak: Penelitian ini bertujuan untuk mengetahui hubungan psychological wellbeing dengan motivasi kerja pegawai. Penelitian ini menggunakan metode kuantitatif korelasional. Subjek dalam penelitian ini ialah 64 pegawai golongan III di Dinas Pendidikan Kota X yang dipilih dengan menggunakan teknik sampling populasi. Data dikumpulkan menggunakan skala likert berupa skala psycgological well-being dan skala motivasi kerja. Teknik analisis data dalam penelitian ini adalah uji analisis korelasi. Hasil penelitian menunjukan bahwa psychological well-being memiliki hubungan yang signifikan dengan motivasi kerja dengan arah hubungan yang positif, dapat dilihat dari signifikansi sebesar 0,000 dan yang artinya sebesar 78,8\% pada motivasi kerja dipengaruhi oleh psychological well-being dan sisanya sebesar $21,2 \%$ dipengaruhi oleh variabel lain yang tidak diukur dalam penelitian ini.
\end{abstract}

Kata kunci: Psychological well being, motivasi kerja

Kerja merupakan hal yang dibutuhkan manusia. Jika manusia ingin memenuhi kebutuhan dalam kehidupannya maka seseorang harus berusaha mencari nafkah agar segala kebutuhan yang di-inginkan terpenuhi. Orang dewasa banyak menghabiskan waktunya dengan bekerja. Seseorang bekerja dengan keras karena ada satu hal yang dicapainya dan dengan harapan bahwa pekerjaannya akan membawanya pada suatu keadaan yang lebih memuaskan dibandingkan sebelumnya dan mendapatkan kesejah-teraan juga dalam pekerjaannya.

Menurut Robbins (2006), pegawai meru- pakan seseorang yang bekerja kepada yang memberikan suatu pekerjaan, baik kerja sebagai pegawai tetap ataupun

Korespondensi tentang artikel ini dapat dialamatkan kepada Kinanthi Kawuryaning Laksmi melalui email : kinantikawuryaning@ymail.com 
pegawai tidak tetap berdasarkan persetujuan kerja secara tertulis ataupun tidak tertulis untuk melakukan pekerjaan dalam suatu jabatan. Seorang pegawai akan memiliki motivasi kerja yang tinggi apabila seseorang memiliki dukungan yang baik dari lingkungan sekitar ataupun dari dalam dirinya sendiri untuk dapat meningkatkan kesejahteraan dalam hidupnya. Dukungan dari orang sekitar maupun lingkungan dapat menjadikan seseorang menjadi giat dalam bekerja dan mampu mencapai target pekerjaan yang telah ditentukan.

Motivasi dalam kerja akan menjadi dasar bagi seseorang untuk berorganisasi dan bisa menjadikan seseorang dapat meraih keberhasilannya. Motivasi adalah suatu proses berupa dorongan seseorang untuk melakukan kegiatan agar tujuannya tercapai., jika suatu tujuan dalam hidup seseorang tercapai, disitulah seseorang akan merasa puas. Motivasi merupakan kekuatan yang dihasilkan dari suatu keinginan untuk memuaskan seseorang dalam pemenuhan kebutuhannya (Handoko, 2011).

Psychological well being merupakan kepuasan yang dimiliki seseorang dalam hidupnya. Menurut Ryff \& Keyes (1995) psychological well being merupakan suatu dorongan individu untuk menggali kemampuan diri untuk memperbaiki kehidupan individu. Psychological well being dapat juga diartikan pada perasaan seseorang tentang aktivitas kehidupan seseorang yang dilakukan sehari-hari.

Motivasi yang dimiliki individu rendah maka individu tidak memiliki dorongan untuk bekerja secara baik. Seseorang yang memiliki motivasi yang tinggi jika dilihat dari pegawai yang bekerja di Dinas Pendidikan Kota X ialah seorang yang memiliki semangat kerja yang tinggi tanpa memandang upah yang didapatkannya dan tidak memilih-milih tugas yang didapatkan karena disisi lain individu tersebut ingin mendapatkan kesejahteraan yang baik dalam hidupnya, jika seorang pegawai yang memiliki motivasi kerja yang tinggi maka pegawai tersebut memiliki kinerja yang baik dalam bekerja, misalkan seorang pegawai akan menyelesaikan tugas dan kewajibannya secara baik dan cepat sehingga pegawai tersebut tidak memiliki pekerjaan yang banyak dan tidak akan pulang hingga larut malam. Hal seperti ini hubungan yang dijalin dengan atasan juga akan menjadi baik dan dapat saling membantu jika ada rekan kerja yang membutuhkan bantuan dalam hal pekerjaan. Pegawai yang memiliki motivasi kerja yang baik maka akan dapat naik ketingkat jenjang pekerjaan yang lebih tinggi, karena pekerjaan dalam Dinas Pendidikan Kota $X$ ini semakin giat pegawai saat bekerja maka pegawai akan mendapatkan timbal balik yang sesuai dengan kerja kerasnya, misalkan pegawai akan mendapatkan uang bonus dari atasannya.

Psychological well being bagi pegawai untuk meningkatkan suatu motivasi pegawai yang ada di Dinas Pendidikan Kota X sesuai dengan Peraturan Walikota di kota yang sama Nomor 82 Tahun 2012 mengenai pemberian tambahan penghasilan kepada Negeri Sipil Daerah yang sesuai dengan Peraturan Walikota di kota yang sama Nomor 13 Tahun 2014 adalah adanya mamin atau makan minum, Tunjangan Penghasilan Pegawai (TPP), dan tunjangan kinerja atau biasa disebut dengan E-Performance.

Iskandar (2009) faktor yang mempengaruhi kesejahteraan karyawan adalah jumlah tanggungan keluarga, pendapatan keluarga, umur, tabungan, beban hutang keluarga karyawan, dan lokasi tempat tinggal karyawan. Psychological well being bagi karyawan harus terpenuhi, karena akan berpengaruh pada peningkatan semangat kerja karyawan dalam suatu perusahaan.

Kesejahteraan seorang pegawai mudah untuk diketahui dengan ada atau tidaknya kebahagiaan dalam bekerja. Ketika seorang dapat menemukan sesuatu yang menye-nangkan dan menarik dalam perkejaannya, maka dalam hal ini dapat 
dikatakan bahwa seseorang tersebut telah senang dengan pekerjaannya dan akan menunjukan suatu kinerja dan potensi yang memuaskan karena kesejahteraannya telah terpenuhi

\section{Metode}

Populasi dalam penelitian yang digunakan sebanyak 64 pegawai golongan III di Dinas Pendidikan Kota X. Penelitian ini yang diambil sebagai populasi adalah subjek yang memiliki karakteristik sebagai berikut :pegawai golongan III dan bekerja di Dinas Pendidikan Kota X. Karena jumlah anggota populasi dalam penelitian ini kurang dari 100 orang, maka seluruh anggota dijadikan sampel penelitian, yaitu berjumlah 64 orang. Sebanyak 32 dari sampel dijadikan subjek try out, sedangkan 32 orang sisanya menjadi subjek penelitian. Variabel bebas (X) dalam penelitian ini adalah psychological well being dan variabel terikat (Y) dalam penelitian ini adalah motivasi kerja. Pengumpulan data dilakukan menggunakan dua instrumen skala Likert, yaitu skala motivasi kerja dan skala psychological well-being. Teknik analisis dilakukan dengan menggunakan uji korelsi product moment dari Pearson dengan bantuan sistem pengolahan data SPSS versi 21.0 for windows. Beberapa uji asumsi dilakukan sebelum analisis data untuk memastikan apakah data telah memenuhi syarat pengukuran parametrik.

\section{a. Uji Normalitas}

Uji normalitas merupakan penggunaan statistik parametrik yang bekerja dengan asumsi pada data dimana setiap variabel dalam penelitian yang akan dianalisis membentuk suatu distribusi yang normal. Bila suatu data tidak normal maka, teknik statistik yang digunakan adalah nonparametrik. Uji normalitas dalam penelitian ini menggunakan test of kolmorov-sminorv dengan menggunakan sistem pengolahan data SPSS versi 21.0 for windows karena dengan menggunakan ini dapat mem- berikan suatu hasil pengujian normalitas yang dapat diketahui batas kenormalan suatu data.

b. Uji Homogenitas

Uji homogenitas dilakukan untuk mengetahui apakah dua variabel yang diambil memiliki varians yang sama atau tidak. Pengujian homogenitas variabel motivasi kerja dan psychological well being dilakukan dengan menggunakan uji Levene's Test for Equality of Variance dengan bantuan SPSS 21.0 for windows.

c. Uji Hipotesis

Dalam uji korelasi pearson product moment, karena terdapat dua variabel yang digunakan dalam penelitian ini. Uji korelasi pearson product moment ini dapat digunakan untuk penelitian dengan jumlah variabel yang lebih dari satu variabel. Uji korelasi pearson product moment ini dapat menggunakan sistem pengolahan data SPSS versi 21.0 for windows.

\section{Hasil dan Pembahasan}

Berdasarkan uji analisis data yang telah dilakukan dengan menggunakan teknik analisis uji korelasi pearson product moment diketahui bahwa psychological well being berhubungan secara signifikan dengan motivasi kerja hubunganya positif, maka semakin tinggi atau positif motivasi kerja maka akan tinggi juga psychological well being. Hal ini dapat dilihat dari $\mathrm{P}$ signifikansi sebesar $0,000(<0,05)$ dan arah hubunganya bersifat positif dengan koefisien sebesar 0,788, sehingga dalam penelitian tersebut menyatakan bahwa "terdapat hubungan antara psychological well being dengan motivasi kerja pegawai golongan III di Dinas Pendidikan Kota X" diterima.

Pada pengolahan data diketahui hasil korelasi pearson product moment sebesar 0,788. Nilai tersebut menunjukan bahwa kontribusi yang diberikan variabel psychological well-being dan motivasi 
kerja pegawai golongan III adalah sebesar 0,788 . Artinya, sebesar $78,8 \%$ variasi pada psychological well-being pegawai golongan III di Dinas Pendidikan Kota X dipengaruhi oleh motivasi kerja dan sisanya sebesar $21,2 \%$ disebabkan oleh variabel lain yang tidak diukur oleh peneliti.

Adanya dua variabel dalam penelitian tersebut, masing-masing variabel sangat berpengaruh, dapat dilihat dari hasil diatas bahwa psychological well-being berpengaruh besar terhadap motivasi kerja pegawai golongan III di Dinas Pendidikan Kota X.

\section{Simpulan}

Sesuai dengan tujuan dari penelitian ini adalah untuk mengetahui hubungan antara psychological well-being dengan motivasi kerja pegawai golongan III di Dinas Pendidikan Kota X, dalam penelitian ini penulis telah mendapatkan hasil penelitian ke arah hubunganya bersifat positif dengan koefisien sebesar 0,788 dan analisis data yang dilakukan oleh peneliti pada pegawai golongan III di Dinas Pendidikan Kota X, dapat di ambil kesimpulan bahwa terdapat hubungan yang signifikan antara psychological well-being dengan motivasi kerja pegawai golongan III di Dinas Pendidikan Kota X dan terdapat hubungan positif yang signifikan antara motivasi kerja dengan psychological wellbeing. Artinya, semakin tinggi motivasi kerja maka akan semakin tinggi pula psychological well-being.

\section{Daftar Pustaka}

Arikunto, S. (2005). Manajemen Penelitian. Jakarta: Rineka Cipta.

Asnawi, S. (2007). Teori Motivasi. Jakarta: Studia Press.

Azwar, S. (2009). Reliabilitas dan Validitas. Yogyakarta: Pustaka Pelajar.

Azwar, S. (2011). Penyusunan Skala Psikologi. Yogyakarta: Pustaka Pelajar.

Munandar, Ashar Sunyato. (2008). Psikologi Industri dan Organisasi. Jakarta: Universitas Indonesia Press.

Narbuko, C., Achmadi, A, H. (2004). Metodologi Penelitian. Jakarta: PT. Bumi Aksara.

Robbins, Stephen P. (2006). Perilaku Organisasi (alih bahasa Benjamin Molan). Edisi Bahasa Indonesia. Klaten: PT. Int An Sejati.
Ryff, C. D. \& Keyes, C. L. M. (1995). The Structure of Psychological Well Being. Journal of Personality and Social Psychology, 69 (4) 719-727.

Siagian, S. (2002). Teori Motivasi dan Aplikasinya. Jakarta: PT. Rineka Cipta.

Sugiyono. (2009). Metode Penelitian Kuantitatif, Kualitatif, dan $R \& D$. Bandung: Alfabeta.

Sugiyono. (2007). Statistika Untuk Penelitian. Bandung: Alfabeta.

Suryabrata, S. (2005). Metodologi Penelitian. Jakarta: PT. Raja Grafindo Persada.

Wibowo, Agung Edy.(2012). Aplikasi Praktis SPSS Dalam Penelitian. Yogyakarta: Gava Media.

Winardi, J. (2002). Motivasi dan Pemotivasian dalam Manajemen. Jakarta : Grafindo Persada. 